\title{
Can a low concentration of an organophosphate insecticide cause negative effects on an aquatic macrophyte? Exposure of Potamogeton pusillus at environmentally relevant chlorpyrifos concentrations
}

\author{
Lidwina Bertrand ${ }^{\mathrm{a}}$, Damián José Marino ${ }^{\mathrm{b}}$, Magdalena Victoria Monferrán ${ }^{\mathrm{c}}$, \\ María Valeria Amé ${ }^{\mathrm{a}, *}$ \\ a Centro de Investigaciones en Bioquímica Clínica e Inmunología - CIBICI, Facultad de Ciencias Químicas, CONICET, UNC, Haya de la Torre esq. Medina \\ Allende, 5000 Córdoba, Argentina \\ ${ }^{\mathrm{b}}$ Centro de Investigaciones del Medio Ambiente (CIMA) Facultad de Ciencias Exactas, CONICET, UNLP, Calle 47 y 115, 1900, La Plata, Argentina \\ ${ }^{\mathrm{c}}$ Instituto de Ciencia y Tecnología de Alimentos Córdoba - ICYTAC, Facultad de Ciencias Químicas, CONICET, UNC, Av. Juan Filloy s/n, Ciudad Universitaria, \\ 5000 Córdoba, Argentina
}

\section{A R T I C L E I N F O}

\section{Article history:}

Received 5 December 2016

Received in revised form 8 March 2017

Accepted 8 March 2017

Available online 19 March 2017

\section{Keywords:}

Organophosphate insecticide

Environmental concentrations

Aquatic macrophyte

Oxidative stress

\begin{abstract}
A B S T R A C T
The contamination of the aquatic environments with organophosphorus pesticides may affect non-target organisms. The aim of this study was to evaluate the toxic effects of the insecticide chlorpyrifos (CPF) at environmental concentrations on the freshwater macrophyte Potamogeton pusillus belonging to a genus of worldwide distribution. For this purpose, individuals were exposed from 3.5 to $94.5 \mathrm{ng}$ of CPF $\mathrm{L}^{-1}$ for $96 \mathrm{~h}$. A battery of biochemical responses including bioaccumulation, defense and damage biomarkers were measured in leaf, stem and root. Even when CPF was not detected in the macrophyte tissues, our results showed that this insecticide promotes oxidative stress and biomolecule damages in $P$. pusillus after acute exposure. Significant response of biomarkers was observed from the lowest tested concentration ( $3.5 \mathrm{ng}$ CPF $\mathrm{L}^{-1}$ ). Oxidative stress was evidenced by increased lipid peroxidation and antioxidant enzymatic activation, including changes in superoxide dismutase, guaiacol peroxidase and glutathione peroxidase activities, especially in leaf. Also, a significant decrease in chlorophyll a and b contents was observed mainly in leaf. Finally, with some selected biomarkers, an Integrated Biomarker Response index was calculated showing a dose-response relationship with CPF exposure. Previous studies reported that herbicides and organophosphorus pesticides are responsible for several effects on photosynthetic systems but at higher exposure concentrations than the tested in this study. These results draw attention to the need for more studies in toxic effects of insecticides on aquatic macrophytes, at low concentrations and different biological levels, since the protection guidelines would not be preserving these species.
\end{abstract}

(C) 2017 Elsevier B.V. All rights reserved.
Abbreviations: [ $\left.C_{10.5}\right], 10.5 \mathrm{ng} \mathrm{L}^{-1} \mathrm{CPF}$; $\left.C_{3.5}\right], 3.5 \mathrm{ng} \mathrm{L}^{-1} \mathrm{CPF} ;\left[C_{31.5}\right], 31.5 \mathrm{ng} \mathrm{L}^{-1}$ CPF; [ $\mathrm{C}_{94.5}$ ], $94.5 \mathrm{ng} \mathrm{L}^{-1} \mathrm{CPF}$; AEWQG, Argentinean Environmental Water Quality Guidelines; BRT, boosted regression trees; Chl, chlorophyll; CPF, chlorpyrifos; Ctrol, control condition; GPx, glutathione peroxidase; GR, glutathione reductase; GSH, reduced glutathione; GSSG, glutathione disulphide; GST, glutathione-S-transferase; IBR, Integrated Biomarker Response; LD, limit of the detection; LQ limit of quantification; NBT, p-nitroblue tetrazolium chloride; OP, organophosphorus pesticides; Pheo, Pheophytins; POD, guaiacol peroxidase; SD, standard deviation; SOD, Superoxide dismutase; TBARs, thiobarbituric acid-reactive substances; ww, wet weight.

* Corresponding author at: CONICET - Universidad Nacional de Córdoba, CIBICI, Facultad Ciencias Químicas, Dto. Bioquímica Clínica- Haya de la Torre esq. Medina Allende, Córdoba 5000, Argentina.

E-mail addresses: vame@fcq.unc.edu.ar, valeriaame@gmail.com (M.V. Amé).

\section{Introduction}

The worldwide consumption of pesticide is about two million tons per year, of which $24 \%$ is consumed in the United States of America alone, $45 \%$ in Europe and $25 \%$ in the rest of the world (Abhilash and Singh, 2009). After decades of extensive use of organochlorine compounds with high environmental persistence, the use of organophosphorus (OP) pesticides increased greatly in the last twenty years. They are widely used because their low persistence in the environment. Usually, pesticides are found in aquatic habitats at varying concentrations because of direct overspray, drift, atmospheric transport and runoff (Gilliom and Hamilton, 2006). Many of them, lack target specificity and have high acute toxicity toward non-target aquatic species being the 
most sensitive taxa among crustaceans, insects and fishes (Van Wijngaarden et al., 2005). Nevertheless, little attention is often attributed to the plants sensitivity and effects, especially aquatic macrophyte.

An extensive bibliography reports the effects of OP on animals, most of them associated with their consequence on diverse physiological activities such as interference of oxidative metabolism, inhibition of respiratory enzymes and inhibition of esterases (Bertrand et al., 2016b; Bonifacio et al., 2016; Giesy and Solomon, 2014). Chlorpyrifos (CPF), O, O-diethyl-O-(3,5,6-trichloro-2-pyridyl) phosphorothioate is a broad-spectrum OP pesticide extensively used for the control of insects. According to John and Shaike (2015), it was estimated that the use of CPF in 2015 would exceed 200,000 tons worldwide, and moreover, an annual growth is expected in global demand for this insecticide. In Argentina, for example, CPF is one of the pesticides most sold, after the herbicide glyphosate, being the insecticide most used in the country (www. casafe.org). Nevertheless, the United States of America and European Union countries banned CPF for domestic use because of the new evidence showing its harmful effects on organisms (EFSA Journal, 2013; Giesy and Solomon, 2014). Others regions under development, including South American and Asiatic countries, are still making an intensive use of this compound without major control (Abhilash and Singh, 2009; Giesy and Solomon, 2014; Pozo et al., 2016 Prasertsup and Ariyakanon, 2011). In this context, runoff from fields to rivers and lakes is expected as well as direct overspray on aquatic environments, with the consequent water contamination and probable toxic effect on organisms. Previous studies reported CPF water contamination, with levels up to $17000 \mathrm{ng} \mathrm{L}^{-1}$ of $\mathrm{CPF}$, in different countries, including Argentina (Giesy and Solomon, 2014; Mugni et al., 2011).

Non target effects of pesticides can be evaluated using biomarkers as "early warning" signs, providing data on the potential adverse impacts on aquatic species (Booth et al., 2003). OP, including CPF, were initially designed to inhibit cholinesterase enzymes, associated to nerve impulse transmission in animals (Collange et al., 2010). This mode of action led to most of the studies conducted about CPF effects, which were carried out with invertebrates (Cooper and Bidwell, 2006; Gagnaire et al., 2008) and vertebrates organisms (Attademo et al., 2015; Wang et al., 2011). Considering the mechanism of action of the OP, we would not expect toxic effects on photosynthetic organisms like plants and algae. However, oxidative stress has been proposed as other molecular mechanisms involved in pesticide induced toxicity (Wang et al., 2013) and few studies could be found about the damages of CPF over pigments concentration, photosynthetic functions, growth and $\mathrm{CO}_{2}$ fixation in plants (Lal et al., 1987; Mishra et al., 2008; Parween et al., 2011).

Plants have multiple strategies to confer their tolerance to insecticide induced toxicity. Prevention of oxidative damage to cells has been suggested as one of the mechanisms of stress tolerance (Parween et al., 2012a,b). During pesticide exposure, the uptake, metabolization and accumulation of these compounds can occur in aquatic macrophytes (Karen et al., 1998; Knuteson et al., 2002; Gao et al., 2000; Hand et al., 2001; Pietsch et al., 2006). Differences in plant metabolism are considered the major cause of variation in pesticides sensitivity among species. The species specific preferences of carbon source $\left(\mathrm{CO}_{2}, \mathrm{HCO}_{3}{ }^{-}\right.$or air) and nutrients ions $\left(\mathrm{NO}_{3}{ }^{-}\right.$or $\left.\mathrm{NH}_{4}^{+}\right)$affect leaf permeability, $\mathrm{pH}$ conditions around roots and in the leaf boundary layer and, the metabolic pathways present in the plants (Cedergreen et al., 2004). All these variables as well as growth rate will determinate the uptake rate of a toxic compound.

The study of biomarkers in native bioindicators results relevant since the sensibility to a toxic compound is specie dependent (van der Oost et al., 2003) and only few previous studies indicated negative effects of water contamination on native biota of South America, particularly for plants (Garanzini and Menone, 2015; Pérez et al., 2008). According to Swanson et al. (1991) aquatic macrophytes were described as more sensitive to pesticides than algae mainly because pesticides (specially herbicides) are often designed to control vascular plants. Nevertheless, another comparative studies indicate than for an important group of chemicals, including herbicides, algal species were more sensitive than macrophytes (Giddings et al., 2013). Despite the differences in obtained conclusions, both authors, showed a wide variability in sensitivity according to chemicals, concentrations and species tested.

The genus Potamogeton is known to be a good candidate for development as test species in non-target plant test guidelines (Swanson et al., 1991). This genus has a cosmopolitan distribution (Novara, 2003; http://www.iucnredlist.org) and an ecological importance within the aquatic ecosystem, providing shelter and habitat for young fishes and other aquatic animals. Sensitivity of Potamonogeton perfoliatus and Potamogeon pectinatus to herbicides like atrazine and fluridone have been reported (Swanson et al., 1991 ). However, less information about Potamonogeton sensitivity to insecticides, including OP, could be found (Hand et al., 2001). Consequently, Potamogeton pusillus has been used as a bioindicator to provide information on environmental quality (Harguinteguy et al., 2016).

The aim of this study was to evaluate the effects of CPF at environmental concentrations on P. pusillus, a South American native species, exposed in laboratory conditions for $96 \mathrm{~h}$. For this purpose, bioaccumulation, damage and defense biomarkers were measured in leaf, stem and root of the macrophyte. The results of these biological responses would help to clarify the mode of toxic action of this insecticide on non-target species. An integrated biomarkers index was also calculated for a more holistic view of the toxic effects, to evaluate at which concentration the macrophyte suffered a significant stress or damages and reinforces the usefulness of $P$. pusillus as bioindicator. According to the described background, the hypothesis was that $P$. pusillus exposed to low concentrations of CPF is able to show changes in biological responses evidencing stress or damages.

\section{Materials and methods}

\subsection{Reagents and materials}

All reagents were of analytical grade supplied by Sigma-Aldrich and Sintorgan (Argentina). All materials used were left with sulfuric-nitric acids solution overnight and then washed with ultra-pure water to avoid contamination. Chlorpyrifos (CPF) analytical standard diluted in acetone was used as stock solution for calibration of insecticide quantification method.

\subsection{Specimens}

Macrophyte, Potamogeton pusillus were collected from a reference site (Córdoba, Argentina; Monferrán et al., 2009; Galanti et al., 2013). Plants were acclimated during two weeks in 40 L glass aquaria filled with $10 \%$ Hoagland's solution and sediment $(1 / 4)$ from the same sampling area. During two weeks, they were maintained at constant laboratory temperature $\left(25^{\circ} \mathrm{C} \pm 1^{\circ} \mathrm{C}\right)$, under a light/dark regime, $14 \mathrm{~h}$ : $10 \mathrm{~h}$ photoperiod (Monferrán et al., 2012).

\subsection{Experimental exposure}

Two days before the beginning of insecticide exposition, organisms were relocated into the exposure aquaria. Plants were 
kept in $1 \mathrm{~L}$ beakers (three plants per beaker, $5-8 \mathrm{~g}$ wet weight-ww per liter) containing 10\% Hoagland's solution, without sediment.

The experimental design involved five experimental conditions: control (Ctrol), organisms exposed to $3.5 \mathrm{ng} \mathrm{L}^{-1} \mathrm{CPF}$ ([C3.5]), $10.5 \mathrm{ng} \mathrm{L}^{-1} \mathrm{CPF}$ ([C10.5]), $31.5 \mathrm{ng} \mathrm{L}^{-1} \mathrm{CPF}$ ([C31.5]) and $94.5 \mathrm{ng} \mathrm{L}^{-1}$ CPF ([C94.5]). CPF exposition was carried out for $96 \mathrm{~h}$ at similar temperature and photoperiod than acclimation. From the stock solution of CPF a standard solution was prepared in water and specific aliquots were taken to provide nominal concentrations. The exposure solution with higher concentration of CPF also contained $0.002 \%$ of acetone. Therefore, acetone was added at $0.002 \%$ to control condition.

Due to unstable nature of CPF during the exposure conditions, all the exposure media, including control condition, were replaced every $24 \mathrm{~h}$ with freshly made solutions. CPF concentrations were measured in medium samples collected in the aquariums $30 \mathrm{~min}$ after the renewal $(0 \mathrm{~h})$ and previous to the daily medium restitution $(24 \mathrm{~h})$. Samples of media were taken at each exposure day along the $96 \mathrm{~h}$. CPF was extracted from exposure media by solid phase extraction as described by Bonansea et al. (2013). The extracts were analyzed by an Agilent 6890 gas chromatograph (Santa Clara, CA, USA) equipped with a microelectron capture detector and a Varian VF-5ms $30 \mathrm{~m} \times 0.25 \mathrm{~mm} \times 0.25 \mu \mathrm{m}$ capillary column (Palo Alto, CA, USA) to separate and identify the pesticide residue (Maggioni et al., 2012). The obtained limits of detection (LD) and quantification (LQ) in aquarium water were 0.7 and $2.1 \mathrm{ng} \mathrm{L}^{-1}$, respectively.

The CPF concentrations tested were selected according to:

1. relevant environmental concentration $\left(\mathrm{CPF}=1.2-17000 \mathrm{ng} \mathrm{L}^{-1}\right.$, Mugni et al., 2011; Bonansea et al., 2013); and

2. the limit recommended by CCME (2012) and AEWQG (2003) for the protection of aquatic biota $\left(\leq 2 \mathrm{ng} \mathrm{L}^{-1}\right.$ and $\leq 6 \mathrm{ng} \mathrm{L}^{-1}$, respectively).

Table 1 shows quantified CPF concentrations ( $\mathrm{ng} \mathrm{L}^{-1}$ ) in the exposure media after $(0 \mathrm{~h})$ and before the medium restitution $(24 \mathrm{~h})$. The decay in pesticide concentration after $24 \mathrm{~h}$ was coincident with previous studies, and varied between $50 \%$ and $100 \%$ (Bertrand et al., 2016b). Insecticide concentrations in control aquariums were below the detection limits of the method.

Fig. 1 shows the experimental design carried out. For each treatment 36 organisms distributed in twelve independent aquaria were exposed (totaling 180 macrophytes). Six pools of two plants were processed, in order to obtain the necessary mass, for the measurement of CPF bioaccumulation. At least six organisms were taken randomly from six independent aquaria for effects biomarkers determination: six for $\mathrm{H}_{2} \mathrm{O}_{2}$, six for lipid peroxidation, six for pigments content, and six for enzyme activity. All measurements were performed in triplicate.

At the end of exposure, macrophytes were washed three times with ultra-pure water, weighed and dissected (leaf, stem and root). Finally, samples were frozen with liquid nitrogen and kept at $-80^{\circ} \mathrm{C}$ until analysis.

\section{Table 1}

Chlorpyrifos concentrations $\left(\mathrm{ng} \mathrm{L}^{-1}\right)$ in medium samples after $(0 \mathrm{~h})$ and before ( $24 \mathrm{~h}$ ) daily medium renewal. Mean \pm standard deviation are indicated for samples taken at each day along the $96 \mathrm{~h}$. The nominal concentration were Control $=0 \mathrm{ng} \mathrm{L}^{-1}$ $\left[C_{3.5}\right]=3.5 \mathrm{ng} \mathrm{L}^{-1},\left[C_{10.5}\right]=10.5 \mathrm{ng} \mathrm{L}^{-1},\left[C_{31.5}\right]=31.5 \mathrm{ng} \mathrm{L}^{-1},\left[C_{94.5}\right]=94.5 \mathrm{ng} \mathrm{L}^{-1}$.

\begin{tabular}{lll}
\hline Experimental conditions & $0 \mathrm{~h}$ & $24 \mathrm{~h}$ \\
\hline Control & $<\mathrm{LD}$ & $<\mathrm{LD}$ \\
{$\left[\mathrm{C}_{3.5}\right]$} & $4.2 \pm 0.7$ & $<\mathrm{LD}$ \\
{$\left[\mathrm{C}_{10.5}\right]$} & $12.6 \pm 1.1$ & $6.3 \pm 1.5$ \\
{$\left[\mathrm{C}_{31.5}\right]$} & $29.0 \pm 7.2$ & $6.9 \pm 1.9$ \\
{$\left[\mathrm{C}_{94.5}\right]$} & $97.5 \pm 2.6$ & $14.0 \pm 13.4$ \\
\hline
\end{tabular}

\subsection{Bioaccumulation of chlorpyrifos}

One gram of homogenized tissues (leaf, stem or root) was weighed in a $15 \mathrm{~mL}$ polypropylene centrifuge tube and $2 \mathrm{~mL}$ of $1 \%$ $\mathrm{v} / \mathrm{v}$ of acetic acid in acetonitrile were added. The mixture was sonicated $5 \mathrm{~min}$ in a cold bath and then, QuEChERS (Waters) extraction bag with $0.8 \mathrm{~g}$ anhydrous $\mathrm{MgSO} 4$ and $0.2 \mathrm{~g}$ sodium acetate was added. The tubes were shaken immediately for $1 \mathrm{~min}$. The sample was then centrifuged for $5 \mathrm{~min}$ at $4000 \mathrm{rpm}$. During the clean-up step, $0.5 \mathrm{~mL}$ upper acetonitrile layer was transferred into a $2 \mathrm{~mL}$ centrifuge tube with $75 \mathrm{mg} \mathrm{MgSO} 4,25 \mathrm{mg}$ PSA (primary and secondary amine) and $5 \mathrm{mg}$ of graphitized carbon black (Waters). The tubes were shaken immediately for $1 \mathrm{~min}$ and centrifuged for $2 \mathrm{~min}$ at $3500 \mathrm{rpm}$. Supernatant was transferred to vial, $10 \mu \mathrm{L}$ of $1-$ octanol was added, and the extract was reduced to nearly dryness with nitrogen. Finally, the residue was re-dissolved with $600 \mu \mathrm{L}$ of $n$-hexane, then introduced into an auto sampler vial for Gas Chromatography coupled with Electron Capture Detector analysis (GC-ECD; Maggioni et al., 2012). Recovery percentages of CPF were previously evaluated from spiked samples obtaining values of $89 \pm 5 \%$.

\subsection{Effects biomarkers}

\subsubsection{Hydrogen peroxides}

The hydrogen peroxide $\left(\mathrm{H}_{2} \mathrm{O}_{2}\right)$ concentration was determined according to Jana and Choudhuri (1981) in extracts of leaf, stem and root of macrophytes prepared in sodium phosphate solution ( $50 \mathrm{mM}, \mathrm{pH}$ 6.5). The pertitanic acid $\left(\mathrm{H}_{2} \mathrm{TiO}_{4}\right)$ generation, after the reaction of $\mathrm{H}_{2} \mathrm{O}_{2}$ with titanium sulfate dissolved in a $\mathrm{H}_{2} \mathrm{SO}_{4}$, was measured by spectrophotometry at $415 \mathrm{~nm}$. Results were expressed in $\mathrm{mg}_{2} \mathrm{O}_{2} \mathrm{~g}^{-1} \mathrm{ww}$.

\subsubsection{Lipid peroxidation}

Lipid peroxidation was estimated by determining the thiobarbituric acid-reactive substances (TBARs) content in aqueous extracts of $P$. pusillus according to Heath and Parker (1968). The amount of present TBARs was calculated using an extinction coefficient of $155 \mathrm{mM} \mathrm{cm}^{-1}$. Results were expressed in $\mathrm{nmol} \mathrm{g}^{-1}$ wet weight (ww).

\subsubsection{Pigments content}

Chlorophyll ( $\mathrm{Chl}$ ) and pheophytins (Pheo) concentrations were determined in leaf and stem of $P$. pusillus according to Wintermans and de Mots (1965). Concentrations of pigments in plant extracts were measured by visible spectrophotometry using a microplate reader $(\mathrm{Chl}=649$ and $665 \mathrm{~nm}$; Pheo $=654$ and $666 \mathrm{~nm}$, after hydrochloric acid addition). Concentrations were calculated and reported in $\mu \mathrm{g}$ pigment $\mathrm{g}^{-1} \mathrm{ww}$.

\subsubsection{Enzyme extraction and measurement}

Enzyme extracts of $P$. pusillus were prepared according to Monferrán et al. (2009). After removal of cell debris (10 min at $\left.13,000 \mathrm{~g}, 4^{\circ} \mathrm{C}\right)$, the membrane fraction of the extracts was separated by centrifugation at $105,000 \mathrm{~g}$ for $60 \mathrm{~min}$. The remaining supernatant, defined as the soluble (cytosolic) fraction was used for enzyme measurement. Enzymatic activities were determined by spectrophotometry, using a microplate reader (Bio-Tek, Synergy HT).

The activity of cytosolic and membrane bound glutathione-Stransferase (GST; EC 2.5.1.18) was measured according to Habig et al. (1974) using 1-chloro-2, 4-dinitrobenzene (CDNB) as substrate. The glutathione reductase activity (GR; EC 1.8.1.7) was assayed according to Tanaka et al. (1994). GR reduces added glutathione disulphide (GSSG) to reduced glutathione (GSH), spectrophotometrically consuming added NADPH. The activity of 


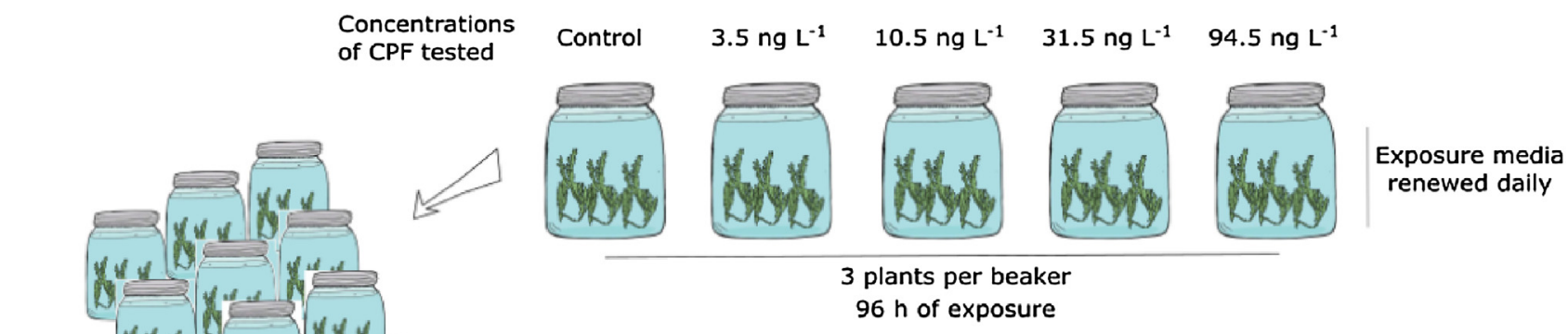

12 beakers per treatment
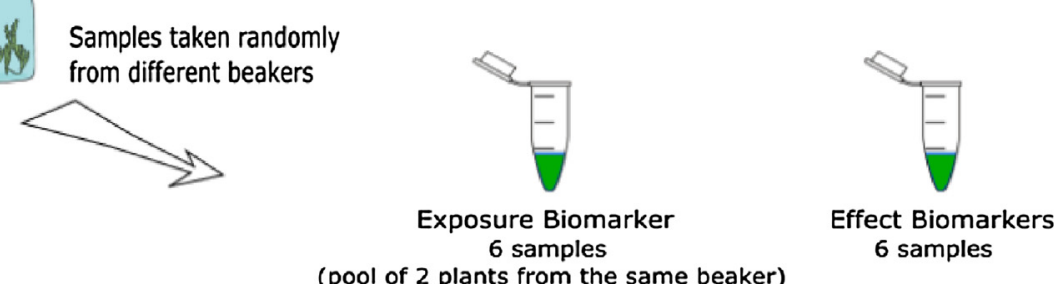

Measurements performed in triplicate

Fig. 1. Experimental design used for exposure of $P$. pusillus at different CPF concentrations for $96 \mathrm{~h}$.

glutathione peroxidase (GPx; EC 1.11.1.9) was determined as reported by Drotar et al. (1985) using hydrogen peroxide $\left(\mathrm{H}_{2} \mathrm{O}_{2}\right)$ as substrate. The guaiacol peroxidase (POD) activity was measured using guaiacol and $\mathrm{H}_{2} \mathrm{O}_{2}$ (Bergmeyer, 1983). Superoxide dismutase activity was determined by using the photochemical $p$-nitroblue tetrazolium chloride (NBT) reduction method as described by Aiassa et al. (2010) (SOD; EC 1.15.1.1).

The activity of all enzymes assessed was calculated in terms of the protein content of the sample extract (Bradford, 1976) and is reported in nanokatals per milligram of protein (nkat mg prot-1), where 1 nkat is the conversion of $1 \mathrm{nmol}$ of substrate per second. Likewise, one unit of SOD activity is defined as the amount of enzyme required to cause $50 \%$ inhibition in the reduction of NBT. The protein quantification was performed using bovine serum albumin as standard.

\subsection{Data analysis}

\subsubsection{Statistical treatment}

Data were expressed as the average \pm standard deviation (SD). Generalized Linear Mixed Model was used for the statistical analysis. Normality and variance homogeneity were tested and variance function was applied if necessary. A posteriori test, LSD Fisher test, with the corresponding Bonferroni errors correction, was used to prove for significant differences between the means of control and other treatments $(\mathrm{p}<0.05)$. R Studio and Infostat (Version 2013p, Di Rienzo et al., 2016) were used for all statistical analysis.

\subsubsection{Boosted regression trees and integrated biomarkers response}

The aim of this analysis is to determine those effect biomarkers with higher capacity to explain or predict the exposure concentrations of CPF. Boosted regression trees (BRT) have been fitted according to procedure described by Bertrand et al. (2016a). Briefly, the model was constructed with the GBM packages (Ridgeway, 2013 ) in R (version 0.98.953), using the code described by Elith et al. (2008) including those biomarkers with significant differences to control condition. This method builds a sequence of models of increasing complexity, in order to describe relationships between the response variable (exposure CPF concentration) and the predictor variables (effect biomarkers) getting the variance percentage of the response variable explained by each biomarker
(BRT\%). Considering our sample size, we set tree complexity at 2. The PRESS function was applied to know the capacity of each biomarker selected to predict the CPF exposure concentration.

One general stress index, termed "Integrated Biomarker Response", was afterwards calculated with the selected biomarkers in each plant sector of $P$. pusillus. This IBR was performed in accordance to Beliaeff and Burgeot (2002) with modifications by Devin et al. (2014). Several IBRs were calculated from the same data changing the order of the biomarkers and using the median of all the index values as the final index value. Kruskall Wallis test was carried out to identify IBR differences between treatments.

\section{Results and discussion}

\subsection{Bioaccumulation}

The concentration of CPF was below the detection limit of the method in all the extracts of leaf, stem and root of all analyzed plants ( $3 \mathrm{ngg}^{-1} \mathrm{CPF}$ wet weight) (data not shown). Our results could be indicating that the biotransformation mechanisms in macrophyte are enough to avoid the accumulation of the parental compound, at least at the exposure concentrations tested.

In macrophytes enzymes could metabolize OP, after they reach the plant cells, trough different pathways: 1- P-450 mediated oxidation 2- Hydrolytic transformation predominantly via esterases, amidases, aryl acylamidases and nitrilases. 3- Aromatic dehalogenation trough nitroreductases or 4- Conjugation with sugar, amino acid or GSH (Ven Eerd et al., 2003). At the same time, this transformation is dependent on different factors including physicochemical properties of the compounds, plant species, and environmental factors (Gao et al., 2000).

Previous studies reported that some aquatic plants possess nonspecific hydrolytic enzymes able to degrade OP insecticide probably as a remediation potential. The capacity of acid phosphatase from the aquatic plant Spirodela oligorrhiza to transform OP, has been explored by Hoehamer et al. (2005). In this species, even though OP transformation was verified, a wide variability in the capacity of biotransformation enzymes was obtained depending on the characteristics of the tested compounds (Gao et al., 2000; Hoehamer et al., 2005).On the other hand, Prasertsup and Ariyakanon (2011) reported the capacity of some aquatic macrophytes, like Pistia stratiotes and Lemna minor, to 


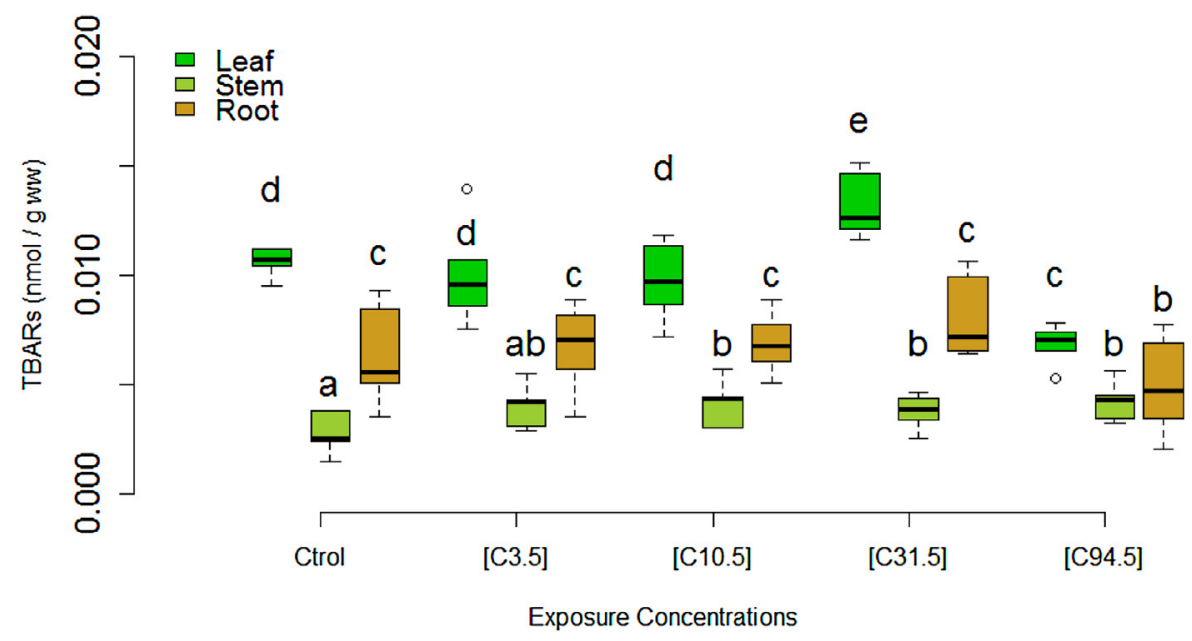

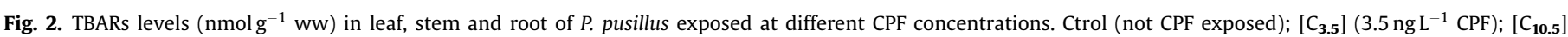

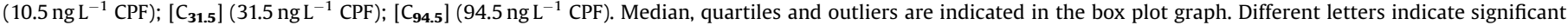
differences $(\mathrm{p}<0.05)$ among treatments and plant sectors.

sequester significant amounts of CPF from the water column. These authors also described a significant inhibition of grow rates in the mentioned species at $1 \mathrm{mg} \mathrm{L}^{-1}$ of CPF. Nevertheless, poor information was found about OP compound metabolites, including CPF, in plants. Baerg et al. (1996) described the capacity of some OP compounds (CPF, permethrin, malathion, among others) to inhibit the biotransformation enzyme cytochrome P450 in maize. Their results indicate that $\mathrm{CPF}$ was able to inhibit this enzyme causing a decline in activity of 46\% (Baerg et al., 1996), probably decreasing the rate of $\mathrm{CPF}$ transformation to oxon-analog.

The main route of metabolism of CPF in plants is via cleavage of the P-O-pyridinol function to give 3, 5, 6-trichloro-Z-pyridinol which is then conjugated. Desulfuration to the oxon has also been reported. Most studies have shown that the CPF which is taken up by the foliage of plants is rapidly metabolized to 3,5,6-trichloro-2pyridinol which is then sequestered by the plant as glycoside conjugates (Roberts and Hutson, 1999).

\subsection{Damages and defenses biomarkers}

Pesticides, and particularly OP, are well known to cause oxidative stress in animals (Valavanidis et al., 2006; Wang et al., 2013). However, less information of oxidative stress occurrence in photosynthetic organisms can be found in literature. Some studies reported the negative effects on growth and photosynthetic activity in Potamogeton species when exposed to different herbicides (Arts et al., 2008; Knauert et al., 2010; Fleming et al., 1995). Nevertheless, the effects of CPF on aquatic macrophytes, and especially Potamogeton genus, have been poorly studied.

The pigments content did not allow us to measure hydrogen peroxides in the samples. Nevertheless, oxidative damage of lipids (TBARs) was observed (Fig. 2).

Levels of lipid peroxidation increased a $24 \%$ in leaf at $\left[C_{31.5}\right]$, while the concentration decreased a $35 \%$ at $\left[\mathrm{C}_{\mathbf{9 4 . 5}}\right]$, both respect to control condition. Stem, showed significant damages on lipids from $\left[C_{10.5}\right]$ to the higher exposure concentration, increasing between 34 and 50\% compared to control condition. Finally, roots presented a decrease in this response at $\left[\mathrm{C}_{\mathbf{9 4 . 5}}\right]$ reaching a $21 \%$ less than control condition, similar to the response observed at the higher exposure concentration in leaves. The TBARs levels variation among plants sectors were according to leaf $>$ root $>$ stem. Hazarika et al. (2003) reported than lipid peroxidation may be the first step of cellular membrane damage by OP compound. In agreement with our results, Song et al. (2007) described the increase of TBARs levels in leaves of wheat plants exposed to an herbicide. Moreover, Vigna radiata exposed to CPF suffered

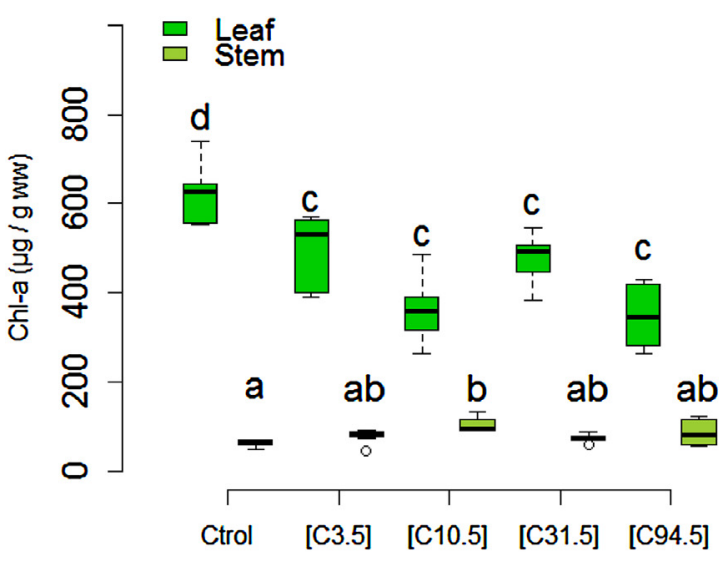

Exposure Concentrations

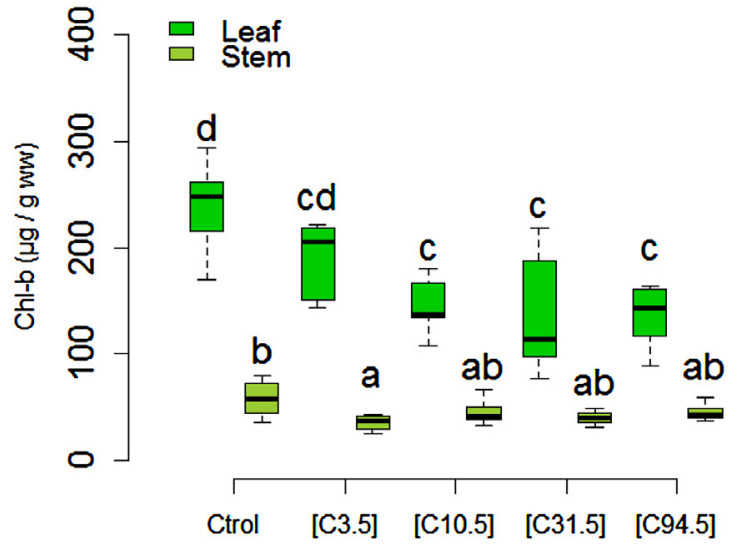

Exposure Concentrations

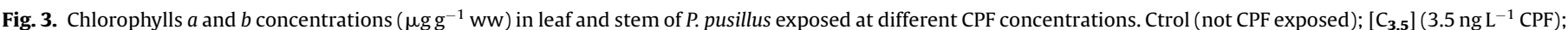

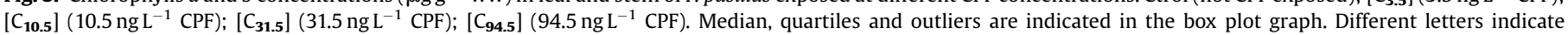
significant differences $(\mathrm{P}<0.05)$ among treatments and plant sectors. 

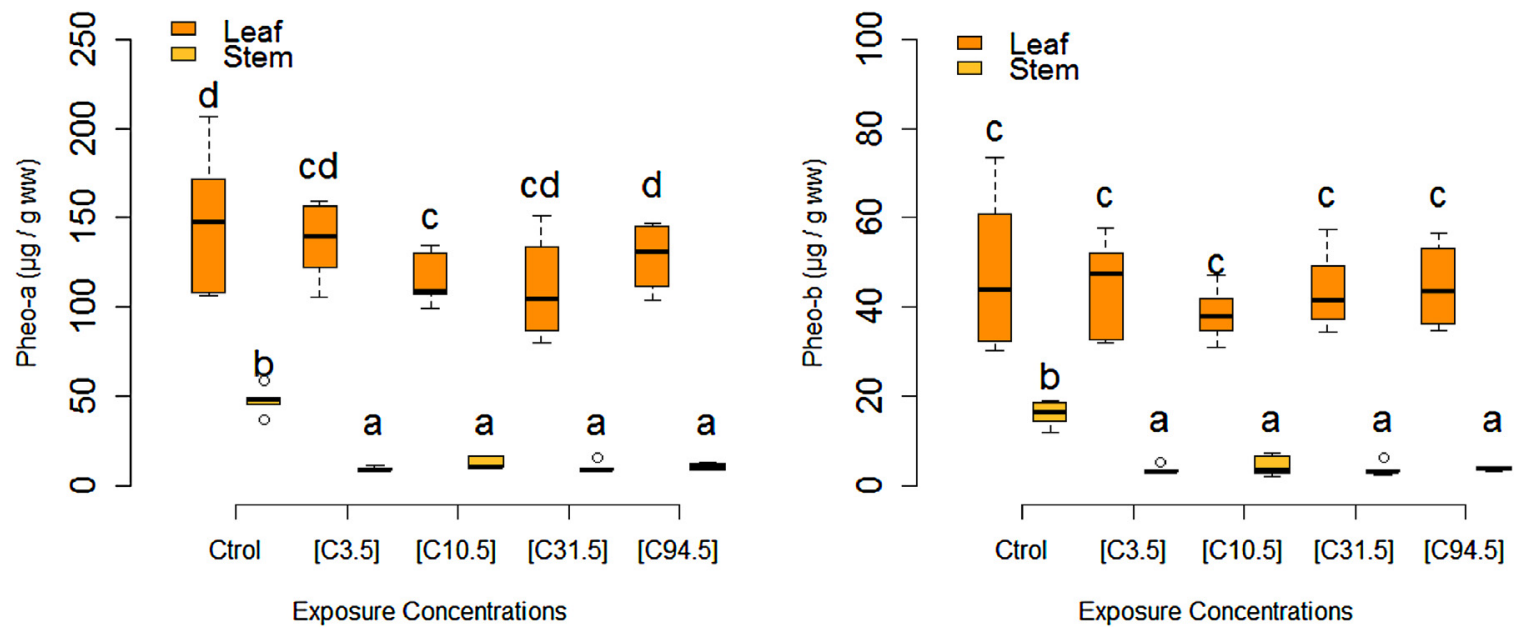

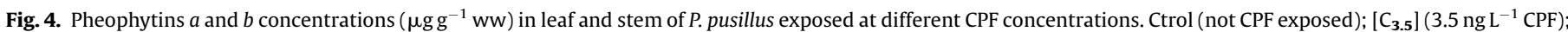

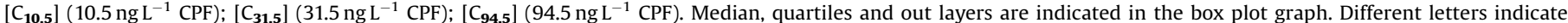
significant differences $(\mathrm{p}<0.05)$ among treatments and plant sectors.

oxidative stress increasing its TBARs levels (Parween et al., 2012a, b). The decay in TBARs concentrations observed at $\left[C_{94.5}\right]$ in $P$. pusillus could be indicating the occurrence of degradation mechanisms of damaged lipid (Kohen and Nyska, 2002). Schweikert and Burritt (2012), reported an increase followed by a decline of lipid peroxidation in Ulva pertusa exposed to an OP compound. The authors also mention that the lipid peroxides can be removed via conversion to alcohols by phospholipid hydroperoxide glutathione peroxidases or by the action of phospholipases, with the resulting free fatty acid peroxides rendered harmless by the action of glutathione peroxidases.

Fleming et al. (1995) reported significant effects of 11 herbicides on Potamogeton pectinatus, showing inhibition in the photosynthetic activity at $4 \mathrm{ng} \mathrm{L}^{-1}$ of a triazine herbicide. Less information is available about insecticides damages over pigments content in macrophytes. In our experiments, significant damages in macrophyte pigments have been observed in $P$. pusillus exposed to CPF. The chlorophylls and pheophytins content are displayed in Figs. 3 and 4, respectively. In leaf, the concentrations of Chl $a$ decreased significantly from $\left[C_{3.5}\right]$. Similarly, $C h l b$ in leaf diminished significantly, starting at $\left[\mathrm{C}_{\mathbf{1 0 . 5}}\right]$. Maximum decay was observed at the higher exposure concentration $\left(94.5 \mathrm{ng} \mathrm{L}^{-1}\right)$ where the chlorophylls contents were $55 \%$ lower than control condition. In stem, the observed response pattern was not as clear as on the leaf. The Chl $b$ suffered a significant degradation at $\left[C_{3.5}\right]$ but not at the others exposure concentrations, while $\mathrm{Chl} a$ increased at intermediate exposure concentration $\left(\left[\mathrm{C}_{\mathbf{1 0 . 5}}\right]\right)$. Chl $a$ is well known to be more sensitive to oxidative stress than others pigments (Kong et al., 1999).In fact, in P. pusillus exposed to CPF Chl $a$ showed a higher sensitivity than $\mathrm{Chl} b$ in leaf, responding from $\left[C_{3.5}\right]$.

In leaf, the Pheo $a$ content showed a decrease tendency from $\left[C_{3.5}\right]$ to $\left[C_{94.5}\right]$, being significant only at $\left[C_{\mathbf{3 1 . 5}}\right]$ when compared to control condition (Fig. 4). The Pheo $b$ showed a similar tendency, although non-significant. In stem, a significant decay in Pheo $a$ and $b$ concentrations has been observed at all tested concentrations.

Few authors described significant effects of OP on photosynthetic system, especially on pigments content and growth in plants and algae. Nevertheless, usually, no significant effects are reported in algae and plants exposed to low doses of pesticides, including OP. The growth inhibition of this organisms is informed at higher exposure concentrations $\left(\mathrm{mg} \mathrm{L}^{-1}\right)$ than tested here $\left(\mathrm{ng} \mathrm{L}^{-1}\right.$; Mishra et al., 2008; Mostafa and Helling, 2002). Singh et al. (2011) reported

Table 2

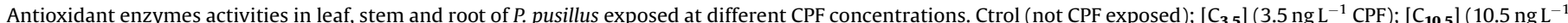

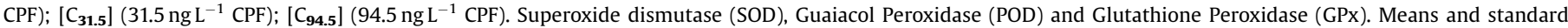
deviation (SD) are indicated. Different letters indicate significant differences $(P<0.05)$ among treatments and plant sectors.

\begin{tabular}{|c|c|c|c|c|c|c|c|c|c|c|c|c|}
\hline & & \multicolumn{3}{|l|}{ Leaf } & & \multicolumn{3}{|l|}{ Stem } & & \multicolumn{3}{|l|}{ Root } \\
\hline & & Means & SD & & & Means & SD & & & Means & SD & \\
\hline \multicolumn{13}{|l|}{ SOD } \\
\hline \multirow[t]{5}{*}{$U \mathrm{mg}^{-1}$ proteins } & Ctrol & 0.04 & 0.02 & $a$ & Ctrol & 0.26 & 0.03 & c & Ctrol & 0.79 & 0.09 & $e$ \\
\hline & {$\left[C_{3.5}\right]$} & 0.09 & 0.02 & $b$ & {$\left[C_{3.5}\right]$} & 0.2 & 0.07 & c & {$\left[C_{3.5}\right]$} & 0.98 & 0.18 & $e$ \\
\hline & {$\left[C_{10.5}\right]$} & 0.04 & 0.01 & $a$ & {$\left[\mathrm{C}_{10.5}\right]$} & 0.13 & 0.03 & $b$ & {$\left[\mathrm{C}_{10.5}\right]$} & 0.3 & 0.06 & $d$ \\
\hline & {$\left[C_{31.5}\right]$} & 0.03 & 0.03 & $a$ & {$\left[\mathrm{C}_{31.5}\right]$} & 0.14 & 0.04 & $b$ & {$\left[\mathrm{C}_{31.5}\right]$} & 0.34 & 0.14 & $d$ \\
\hline & {$\left[\mathrm{C}_{94.5}\right]$} & 0.09 & 0.02 & $b$ & {$\left[\mathrm{C}_{94.5}\right]$} & 0.22 & 0.09 & $c$ & {$\left[C_{94.5}\right]$} & 0.39 & 0.06 & $d$ \\
\hline \multicolumn{13}{|l|}{ POD } \\
\hline \multirow[t]{5}{*}{ nkat $\mathrm{mg}^{-1}$ proteins } & Ctrol & 235.3 & 86.6 & $c$ & Ctrol & 62.2 & 12.5 & $b$ & Ctrol & 70.1 & 12.2 & $b$ \\
\hline & {$\left[\mathrm{C}_{3.5}\right]$} & 254.6 & 37.8 & $c$ & {$\left[C_{3.5}\right]$} & 76.5 & 22 & $b$ & {$\left[\mathrm{C}_{3.5}\right]$} & 88.4 & 15.7 & $b$ \\
\hline & {$\left[C_{10.5}\right]$} & 211.1 & 40.3 & $c$ & {$\left[C_{10.5}\right]$} & 66 & 17.9 & $b$ & {$\left[C_{10.5}\right]$} & 81 & 27.4 & $b$ \\
\hline & {$\left[C_{31.5}\right]$} & 306.5 & 85.4 & $c$ & {$\left[C_{31.5}\right]$} & 47.2 & 13.3 & $b$ & {$\left[C_{31.5}\right]$} & 81.9 & 17.1 & $b$ \\
\hline & {$\left[\mathrm{C}_{94.5}\right]$} & 489.7 & 164.2 & $d$ & {$\left[\mathrm{C}_{94.5}\right]$} & 79.1 & 18 & $b$ & {$\left[\mathrm{C}_{94.5}\right]$} & 97.5 & 10.5 & $b$ \\
\hline \multirow{6}{*}{$\begin{array}{l}\text { GPx } \\
\text { nkat } \mathrm{mg}^{-1} \text { proteins }\end{array}$} & & & & & & & & & & & & \\
\hline & Ctrol & 0.58 & 0.34 & $a$ & Ctrol & 0.59 & 0.32 & $a$ & Ctrol & 0.41 & 0.15 & $a$ \\
\hline & {$\left[C_{3.5}\right]$} & 1.03 & 0.32 & $a b$ & {$\left[C_{3.5}\right]$} & 0.57 & 0.4 & $a$ & {$\left[C_{3.5}\right]$} & 0.65 & 0.11 & $a$ \\
\hline & {$\left[C_{10.5}\right]$} & 0.75 & 0.28 & $a b$ & {$\left[C_{10.5}\right]$} & 0.29 & 0.14 & $a$ & {$\left[\mathrm{C}_{10.5}\right]$} & 0.56 & 0.21 & $a$ \\
\hline & {$\left[C_{31.5}\right]$} & 1.12 & 0.48 & $b$ & {$\left[\mathrm{C}_{31.5}\right]$} & 0.36 & 0.21 & $a$ & {$\left[\mathrm{C}_{31.5}\right]$} & 0.46 & 0.13 & $a$ \\
\hline & {$\left[\mathrm{C}_{94.5}\right]$} & 3.34 & 0.45 & $c$ & {$\left[\mathrm{C}_{94.5}\right]$} & 0.47 & 0.22 & $a$ & {$\left[\mathrm{C}_{94.5}\right]$} & 0.5 & 0.19 & $a$ \\
\hline
\end{tabular}


Table 3

Boosted Regression Trees (BRT) and PRESS values for P. pusillus: Percentages (\%) of Y variability (exposure concentration) explained by each predictor variable (biomarkers response). Press values are shown for each biomarker. Bold values indicate selected biomarkers.

\begin{tabular}{llll}
\hline Bm & Plant Sector & BRT $(\%)$ & PRESS \\
\hline TBARs & Leaf & 30.6 & 0.13 \\
GPX & Leaf & 27.9 & 0.66 \\
POD & Leaf & 17.6 & 0.55 \\
Chl $b$ & Leaf & 6.9 & 0.20 \\
Pheo $a$ & Leaf & 3.0 & 0.00 \\
SOD & Root & 2.6 & 0.19 \\
TBARs & Root & 2.6 & 0.02 \\
SOD & Leaf & 2.2 & 0.00 \\
TBARs & Stem & 1.8 & 0.02 \\
Chl $a$ & Leaf & 1.1 & 0.23 \\
SOD & Stem & 1.0 & 0.00 \\
Chl $a$ & Stem & 0.9 & 0.00 \\
Chl $b$ & Stem & 0.7 & 0.00 \\
Pheo $a$ & Stem & 0.6 & 0.10 \\
Pheo $b$ & Stem & 0.5 & 0.00 \\
\hline
\end{tabular}

the $77 \%$ inhibition of growth in cyanobacterium Synechocystis sp. exposed to $10 \mathrm{mg} \mathrm{L}^{-1}$ CPF. In line with these results, Yadav (2015) reported a decrease in Chl $a$ pigments at $0.5 \mathrm{mg} \mathrm{L}^{-1}$ with maximal decay at $10 \mathrm{mg} \mathrm{L}^{-1}$ in Spirulina exposed to CPF. In both cases, exposure concentrations were in $\mathrm{mg} \mathrm{L}^{-1}$ while our results are indicating negative effects on pigments levels of $P$. pusillus, especially Chl $a$, at lower concentrations (from $3.5 \mathrm{ng}$ CPF $\mathrm{L}^{-1}$ ). Our results show the importance of low dose testing and the inclusion of molecular biomarker response as complementary information to the endpoints usually used for regulatory purposes.

To mitigate and repair the damage caused by enhanced reactive oxygen species, plants have evolved complex antioxidant systems. The activation of enzymatic and non-enzymatic systems have been reported in photosynthetic organisms exposed to pesticides (Arora et al., 2002). Superoxide dismutase is a major scavenger of superoxide, and its enzymatic action results in the formation of $\mathrm{H}_{2} \mathrm{O}_{2}$ and $\mathrm{O}_{2}$. The hydrogen peroxide produced is then scavenged by catalase and a variety of peroxidases. The POD decomposes $\mathrm{H}_{2} \mathrm{O}_{2}$ by oxidation of co-substrates such as phenolic compounds or antioxidants, being the GSH one of the most important antioxidants that occurs in biological systems. Finally, GPx participate to reduce lipid hydroperoxides to alcohol, with the concomitant oxidation of GSH to GSSG (Regoli et al., 2011).

In $P$. pusillus exposed to CPF an increase in SOD activity has been observed at $\left[C_{94.5}\right]$ in leaf, probably indicating the presence of oxygen radicals. In contrast, a significant inhibition occurred in root from $\left[\mathrm{C}_{\mathbf{1 0 . 5}}\right]$ to $\left[\mathrm{C}_{\mathbf{9 4 . 5}}\right]$, whereas in stem, inhibition only occurred significantly at intermediate concentrations $\left(\left[\mathrm{C}_{\mathbf{1 0 . 5}}\right]\right.$ and $\left[\boldsymbol{C}_{\mathbf{3 1 . 5}}\right]$ ) (Table 2). Parween et al. (2012a,b) reported the induction of SOD and ascorbate peroxidase activities. Ascorbate peroxidase is an enzyme with similar function than POD, measured in Vigna radiate exposed to $\mathrm{CPF}$. In leaf of $P$. pusillus the POD activity showed a tendency to increase from $\left[C_{3.5}\right]$ with a significant induction only at the higher exposure concentration, while no significant variation occurred in the others plant sectors (Table 2). Induction of POD and SOD activity has been previously reported by Ganguly et al. (2010) in Lathyrus sativus L. exposed to OP. Finally, the GPx activity was affected only in leaf of $P$. pusillus, where a tendency to enzymatic activation was observed from $\left[C_{3.5}\right]$ even though it was significant at $\left[C_{\mathbf{3 1 . 5}}\right]$ and $\left[C_{\mathbf{9 4 . 5}}\right]$. The rise of TBARs could be the cause of GPx increased activity at the higher exposure concentrations, in this plant sector. No enzymatic activity was detected for GST and GR in all plant sectors. According to our results, enzymatic antioxidant systems showed a higher response in leaf compared with stem and root. Probably, the enhanced enzymes response in leaf could be indicating an attempt to protect photosynthetic system and other biomolecules.

\subsection{Boosted regression trees (BRT) and integrated biomarkers response (IBR)}

Integrated Biomarkers Response (IBR) index constitutes a practical and robust tool to assess the susceptibility of an exposed organism to pollutants using multiple biomarker responses (Beliaeff and Burgeot, 2002). Nevertheless, the calculation of IBR needs a previous selection of biological responses to be considered. The use of boosted regression trees (BRTs) is a valid tool to select those biomarkers to be used in IBR (Bertrand et al., 2016a). Therefore, biomarkers from the three plant sectors with a significant variation respect to control condition were used to fit a BRT model. Table 3 shows the percentages of exposure concentration variability explained by each variable (biomarkers), where only two biomarkers, GPx and POD activity in leaf, showed a good PRESS value $(\geq 0.5)$.

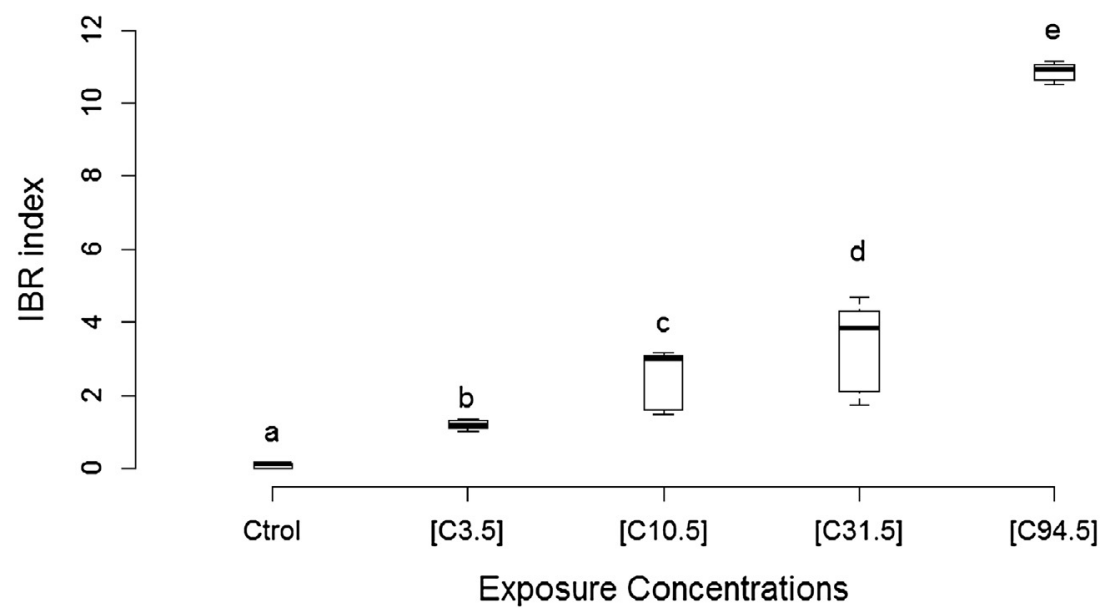

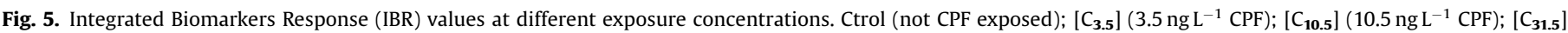

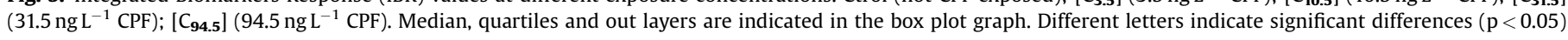
among treatments. 
Considering these results, it could be assumed that the others biomarkers did not have the best capacity to predict, probably indicating a low capability of $P$. pusillus to reflect CPF exposure concentrations, at least with biomarkers here measured. Nevertheless, the biomarkers explaining a high percentage of variability in the exposure concentrations tested were considered to build an Integrated Biomarker Response (IBR). In this way, TBARs, GPx, POD, Chl $b$ and Pheo $a$, all of them measured in leaf, explained (all together) more than $85 \%$ of variability, allowing us to calculate the stress level suffered by P. pusillus. The obtained results are shown in Fig. 5.

Significant increased IBR values were observed for all CPF exposures when compared to the control condition. According to these results $P$. pusillus exposed to CPF suffered a significant stress respect to control organisms even at the lower concentration tested ( $\left.3.5 \mathrm{ng} \mathrm{L}^{-1}\right)$.

\section{Conclusions}

In the present study, toxic effects of CPF at environmental concentrations on $P$. pusillus were analyzed using a battery of biochemical responses including bioaccumulation, defense and damage biomarkers. Even when CPF was not detected in macrophyte tissues, our results showed that this insecticide promotes oxidative stress and biomolecule damages in $P$. pusillus after an acute exposure. On the one hand, oxidative stress was evidenced by increased TBARs and antioxidant enzymatic activation, including SOD, POD and GPx, especially in leaf. On the other hand, significant decrease in chlorophylls contents was observed mainly in leaf from $3.5 \mathrm{ng} C P F \mathrm{~L}^{-1}$. Finally, the integration of selected biomarkers in the IBR showed a dose-response relationship with CPF exposure. These last results are interesting if we consider that previous studies reported that herbicides and OP compounds are responsible for several effects on photosynthetic systems but at higher exposure concentrations than here evaluated. Our study contributes with new data on aquatic plant toxicity at molecular level, with different endpoints parameters from those usually taken into account for regulation purposes of insecticides (as growth rate and biomass). These results draw attention to the need for more studies in toxic effects of insecticides at different biological levels on aquatic macrophytes, especially at low dose, since these compounds are ubiquitous and, probably, the protection guidelines levels would not be preserving these species.

\section{Acknowledgments}

This work was supported by grants from the Agencia Nacional de Promoción Científica y Técnica (FONCyT-PICT/; 2013-1348), Secretaría de Ciencia y Técnica (SECyT) and CONICET (National Research Council, Argentina). The present work is part of the PhD thesis of L. Bertrand, who gratefully acknowledges fellowship from CONICET.

\section{References}

AEWQG, 2003. AEWQG (Argentinean Environmental Water Quality Guidelines; Niveles Guía Nacionales de Calidad de Agua Ambiente). Subsecretaria de Recursos Hídricos de la Nación, República 23 Argentina, 2003.

Abhilash, P.C., Singh, N. 2009. Pesticide use and application: an Indian scenario. J. Hazard. Mater. 165, 1-12. doi:http://dx.doi.org/10.1016/j.jhazmat.2008.10.061.

Aiassa, V., Barnes, A.I., Albesa, I., 2010. Resistance to ciprofloxacin by enhancement of antioxidant defenses in biofilm and planktonic Proteus mirabilis. Biochem. Biophys. Res. Commun. 393, 84-88. doi:http://dx.doi.org/10.1016/j. bbrc.2010.01.083.

Arora, A., Sairam, R.K., Srivastava, G., 2002. Oxidative stess and antioxidative system in plants. Curr. Sci. 82, 1227-1238.

Arts, G.H.P., Belgers, J.D.M., Hoekzema, C.H., Thissen, J.T.N.M., 2008. Sensitivity of submersed freshwater macrophytes and endpoints in laboratory toxicity tests.
Environ. Pollut. 153, 199-206. doi:http://dx.doi.org/10.1016/j. envpol.2007.07.019.

Attademo, A.M., Mariela Peltzer, P., Carlos Lajmanovich, R., Cabagna-Zenklusen, M., María Junges, C. Lorenzatti, E. Aró, C., Grenón, P. 2015. Biochemical changes in certain enzymes of Lysapsus limellium (Anura: Hylidae) exposed to chlorpyrifos. Ecotoxicol. Environ. Saf. 113, 287-294. doi:http://dx.doi.org/ 10.1016/j.ecoenv.2014.12.021.

Baerg, R., Barrett, M., Polge, N., 1996. Insecticide and insecticide metabolite interactions with cytochrome P450 mediated activities in maize. Pestic Biochem. Physiol. 55, 10-20. doi:http://dx.doi.org/10.1006/pest.1996.0030.

Beliaeff, B., Burgeot, T., 2002. Integrated Biomarker Response: a useful tool for ecological risk assessment. Environ. Toxicol. Chem. 21, 1316-1322.

Bergmeyer, H.U., 1983. Methods of Enzymatic Analysis, vol. I. VCH Weinheim, Germany, pp. 648-653.

Bertrand, L., Asis, R., Monferrán, M.V., Amé, M.V., 2016a. Bioaccumulation and biochemical response in South American native species exposed to zinc: boosted regression trees as novel tool for biomarkers selection. Ecol. Indic. 67, 769-778. doi:http://dx.doi.org/10.1016/j.ecolind.2016.03.048.

Bertrand, L., Monferrán, M.V., Mouneyrac, C., Bonansea, R.I., Asis, R., Amé, M.V., 2016b. Sensitive biomarker responses of the shrimp Palaemonetes argentinus exposed to chlorpyrifos at environmental concentrations: roles of alphatocopherol and metallothioneins. Aquat. Toxicol. 179, 72-81. doi:http://dx.doi. org/10.1016/j.aquatox.2016.08.014.

Bonansea, R.I., Amé, M.V., Wunderlin, M.V., 2013. Determination of prioritypesticides in water samples combining SPE and SPME coupled to GCMS. Acase study: suquéa River basin (Argentina). Chemosphere 90, 1860-1869. doi:http://dx.doi.org/10.1016/j.chemosphere.2012.10.007.

Bonifacio, A.F., Cazenave, J., Bacchetta, C., Ballesteros, M.L., De Los, Ángeles, Bistoni, M., Amé, M.V., Bertrand, L., Hued, A.C., 2016. Alterations in the general condition, biochemical parameters and locomotor activity in Cnesterodon decemmaculatus exposed to commercial formulations of chlorpyrifos, glyphosate and their mixtures. Ecol. Indic. 67, 88-97. doi:http://dx.doi.org/ 10.1016/j.ecolind.2016.02.011

Booth, L.H., Bithell, S.L., Wratten, S.D., Heppelthwaite, V.J., 2003. Vineyard pesticides and their effects on invertebrate biomarkers and bioindicator species in New Zealand. Bull. Environ. Contam. Toxicol. 71, 1131-1138. doi:http://dx.doi.org/ 10.1007/s00128-003-8879-9.

Bradford, M.M., 1976. A rapid and sensitive method for the quantification ofmicrogram quantities of proteins utilizing the principle of proteindyebinding. Anal. Biochem. 72, 248-254.

CCME, 2012. Canadian water quality guidelines for the protection of aquatic life. In Environment, C.C.o.M.o.t. (Ed.), Canadian Environmental Quality Guidelines, 1999. Canadian Council of Ministers of the Environment, Winnipeg.

Cedergreen, N., Streibig, J.C., Spliid, N.H., 2004. Sensitivity of aquatic plants to the herbicide metsulfuron-methyl. Ecotoxicol. Environ. Saf. 57, 153-161. doi:http:// dx.doi.org/10.1016/S0147-6513(02)00145-8.

Collange, B., Wheelock, C.E., Rault, M., Mazzia, C., Capowiez, Y., Sanchez-Hernandez, J.C., 2010. Inhibition, recovery and oxime-induced reactivation of muscle esterases following chlorpyrifos exposure in the earthworm Lumbricus terrestris. Environ. Pollut. 158, 2266-2272. doi:http://dx.doi.org/10.1016/j. envpol.2010.02.009.

Cooper, N.L., Bidwell, J.R., 2006. Cholinesterase inhibition and impacts on behavior of the Asian clam Corbicula fluminea, after exposure to an organophosphate insecticide. Aquat. Toxicol. 76, 258-267. doi:http://dx.doi.org/10.1016/j. aquatox.2005.09.012

Devin, S., Burgeot, T., Giambérini, L., Minguez, L., Pain-Devin, S., 2014. The integrated biomarker response revisited: optimization to avoid misuse. Environ. Sci. Pollut. Res. 21,1-14. doi:http://dx.doi.org/10.1007/s11356-013-2169-9.

Di Rienzo, J.A., Casanoves, F., Balzarini, M.G., Gonzalez, L., Tablada, M., Robledo, C.W., 2016. InfoStat Versión 2016. Grupo InfoStat, FCA. Universidad Nacional de Córdoba, Argentina. http://www.infostat.com.ar.

Drotar, A., Phelps, P., Fall, R., 1985. Evidence for glutathione peroxidase activities in cultured plant cells. Plant Sci. 42, 35-40.

European Food Safety Authority, 2013. International framework dealing with human risk assessment of combined exposure to multiple chemicals. EFSA J. 11 (7), 69. doi:http://dx.doi.org/10.2903/j.efsa.2013.3313 (3313).

Elith, J. Leathwick, J.R., Hastie, T., 2008. A working guide to boosted regression trees. J. Anim. Ecol. 77, 802-813. doi:http://dx.doi.org/10.1111/j.13652656.2008.01390.x.

Fleming, W., James Ailstock, M., Stephen Momot Jeffrey, J., 1995. Net photosynthesis and respiration of sago pondweed (Potamogeton pectinatus) exposed to herbicides. ASTM Spec. Tech. Publ. 1218, 303-317.

Gagnaire, B., Geffard, O., Xuereb, B., Margoum, C., Garric, J., 2008. Cholinesterase activities as potential biomarkers: characterization in two freshwater snails, potamopyrgus antipodarum (Mollusca, hydrobiidae, smith 1889) and valvata piscinalis (Mollusca, valvatidae, Müller 1774). Chemosphere 71, 553-560. doi http://dx.doi.org/10.1016/j.chemosphere.2007.09.048.

Galanti, L.N., Amé, M.V., Wunderlin, D.A., 2013. Accumulation and detoxification dynamic of cyanotoxins in the freshwater shrimp Palaemonetes argentinus. Harmful Algae 27, 88-97. doi:http://dx.doi.org/10.1016/j.hal.2013.05.007.

Ganguly, S., Bhattacharya, S., Mandi, S., Tarafdar, J., 2010. Biological detection and analysis of toxicity of organophosphate- and azadirachtin-based insecticides in Lathyrus sativus L. Ecotoxicology 19, 85-95. doi:http://dx.doi.org/10.1007/ s10646-009-0391-5.

Gao, J., Garrison, A.W., Hoehamer, C., Mazur, C.S., Wolfe, N.L., 2000. Uptake and phytotransformation of organophosphorus pesticides by axenically cultivated 
aquatic plants. J. Agric. Food Chem. 48, 6114-6120. doi:http://dx.doi.org/ $10.1021 /$ jf9904968

Garanzini, D.S., Menone, M.L., 2015. Azoxystrobin causes oxidative stress and DNA damage in the aquatic macrophyte myriophyllum quitense. Bull. Environ. Contam. Toxicol. 94, 146-151. doi:http://dx.doi.org/10.1007/s00128-014-1428 $\mathrm{X}$.

Giddings, J.M., Arts, G., Hommen, U., 2013. The relative sensitivity of macrophyte and algal species to herbicides and fungicides: an analysis using species sensitivity distributions. Integr. Environ. Assess. Manag. 9, 308-318. doi:http:// dx.doi.org/10.1002/ieam.1387.

Reviews of envitonmental contamination and toxicology. In: Giesy, J.P., Solomon, K. R. (Eds.), Ecological Risk Assessment for Chlorpyrifos in Terrestrial and Aquatic Systems in the United States. Springer, London doi:http://dx.doi.org/10.1007/ 978-3-319-03865-0.

Gilliom, R.J., Hamilton, P.A., 2006. Pesticides in the Nation's Streams and Ground Water, 1992-2001, A Summary Fact Sheet. US Geological Survey, Reston.

Habig, W.H., Pabst, M.J., Jakoby, W.B., 1974. Glutathione S-transferases. J. Biol. Chem. 249, 7130-7139.

Hand, L.H., Kuet, S.F., Lane, M.C., Maund, S.J., Warinton, J.S., Hill, I.R., 2001. Influences of aquatic plants on the fate of the pyrethroid insecticide lambda-cyhalothrin in aquatic environments. Environ. Toxicol. Chem. 20, 1740-1745. doi:http://dx.doi. org/10.1002/etc.5620200817.

Harguinteguy, C.A., Noelia Cofré, M., Fernández-Cirelli, A., Luisa Pignata, M., 2016. The macrophytes Potamogeton pusillus L. and Myriophyllum aquaticum (Vell.) Verdc. as potential bioindicators of a river contaminated by heavy metals. Microchem.J.124, 228-234. doi:http://dx.doi.org/10.1016/j.microc.2015.08.014.

Hazarika, A., Sarkar, S.N., Hajare, S., Kataria, M., Malik, J.K., 2003. Influence of malathion pretreatment on the toxicity of anilofos in male rats: a biochemical interaction study. Toxicology 185, 1-8. doi:http://dx.doi.org/10.1016/S0300 483X(02)00574-7.

Heath, R.L., Parker, L., 1968. Photoperoxidation in isolated chloroplasts. I kinetics and stoichiometry of fatty acid peroxidation. Arch. Biochem. Biophys. 125, 189198.

Hoehamer, C., Mazur, C.S., Wolfe, N.L., 2005. Purification and partial characterization of an acid phosphatase from Spirodela oligorrhiza and its affinity for selected organophosphate pesticides. J. Agric. Food Chem. 53, 90-97. doi:http://dx.doi.org/10.1021/jf040329u.

Jana, S., Choudhuri, M.A., 1981. Glycolate metabolism of three submerged angiosperms during aging. Aquat. Bot. 12, 345-354.

John, E.M., Shaike, J.M., 2015. Chlorpyrifos: pollution and remediation. Environ. Chem. Lett. 13, 269-291. doi:http://dx.doi.org/10.1007/s10311-015-0513-7.

Karen, D.J., Joab, B.M., Wallin, J.M., Johnson, K.A., 1998. Partitioning of chlorpytifos water and an aquatic macrophyte (Elodea densa). Chemosphere 37, 1579-1586.

Knauert, S., Singer, H., Hollender, J., Knauer, K., 2010. Phytotoxicity of atrazine, isoproturon, and diuron to submersed macrophytes in outdoor mesocosms. Environ. Pollut. 158, 167-174. doi:http://dx.doi.org/10.1016/j. envpol.2009.07.023.

Knuteson, S.L., Whitwell, T., Klaine, S.J., 2002. Wetlands and aquatic processes influence of plant age and size on simazine toxicity and uptake. J. Environ. Qual. 2096-2103.

Kohen, R., Nyska, A., 2002. Oxidation of biological systems: oxidative stress phenomena, antioxidants, redox reactions, and methods for their quantification. Toxicol. Pathol. 30, 620-650. doi:http://dx.doi.org/10.1080/ 0192623029016672.

Kong, F.X., Hu, W., Chao, S.Y., Sang, W.L., Wang, L.S., 1999. Physiological responses of the lichen Xanthoparmelia mexicana to oxidative stress of SO2. Environ. Exp. Bot. 42, 201-209. doi:http://dx.doi.org/10.1016/S0098-8472(99)00034-9.

Lal, S., Saxena, D.M., Lal, R., 1987. Effects of ddt fenitrothion and chlorpyrifos on growth photosynthesis and nitrogen fixation in anabaena arm 310 and aulosirafertilissima. Agric. Ecosyst. Environ. 19, 197-210.

Maggioni, T., Hued, A.C., Monferrán, M.V., Bonansea, R.I., Galanti, L.N., Amé, M.V. 2012. Bioindicators and biomarkers of environmental pollution in the middlelower basin of the Suquía River (Córdoba, Argentina). Arch. Environ. Cont. Tox. 63, 337-353.

Mishra, V., Srivastava, G., Prasad, S.M., Abraham, G., 2008. Growth, photosynthetic pigments and photosynthetic activity during seedling stage of cowpea (Vigna unguiculata) in response to UV-B and dimethoate. Pestic. Biochem. Physiol. 92, 30-37. doi:http://dx.doi.org/10.1016/j.pestbp.2008.05.003.

Monferrán, M.V., Agudo, J.a.S., Pignata, M.L., Wunderlin, D., 2009. Copper-induced response of physiological parameters and antioxidant enzymes in the aquatic macrophyte Potamogeton pusillus. Environ. Pollut. 157, 2570-2576. doi:http:/ dx.doi.org/10.1016/j.envpol.2009.02.034.

Monferrán, M.V., Pignata, M.L., Wunderlin, D.A., 2012. Enhanced phytoextraction of chromium by the aquatic macrophyte Potamogeton pusillus in presence of copper. Environ. Pollut. 161, 15-22. doi:http://dx.doi.org/10.1016/j. envpol.2011.09.032.

Mostafa, F.I.Y., Helling, C.S., 2002. Impact of four pesticides on the growth and metabolic activities of two photosynthetic algae. J. Environ. Sci. Health B 37, 417-444. doi:http://dx.doi.org/10.1081/PFC-120014873.

Mugni, H., Ronco, A., Bonetto, C., 2011. Insecticide toxicity to Hyalella curvispina in runoff and stream water within a soybean farm (Buenos Aires Argentina).
Ecotoxicol. Environ. Saf. 74, 350-354. doi:http://dx.doi.org/10.1016/j. ecoenv.2010.07.030

Novara, N.J., 2003. Potamogetonaceae dumort. In: Flora del valle de Lerma. Aportes Botánicos de Salta. Serie Flora, 7, 14

Pérez, D.J., Menone, M.L., Camadro, E.L., Moreno, V.J., 2008. Genotoxicity evaluation of the insecticide endosulfan in the wetland macrophyte Bidens laevis L. Environ. Pollut. 153, 695-698. doi:http://dx.doi.org/10.1016/j. envpol.2007.09.014.

Parween, T., Jan, S., Fatma, T., 2011. Alteration in nitrogen metabolism and plant growth during different developmental stages of green gram (Vigna radiata L.) in response to chlorpyrifos. Acta Physiol. Plant. 33, 2321-2328. doi:http://dx. doi.org/10.1007/s11738-011-0772-2.

Parween, T., Jan, S., Fatma, T., 2012a. Evaluation of oxidative stress in Vigna radiata L. in response to chlorpyrifos. Int. J. Environ. Sci. Technol. 9, 605-612. doi:http:// dx.doi.org/10.1007/s13762-012-0095-x.

Parween, T., Jan, S., Fatma, T., 2012b. Evaluation of oxidative stress in Vigna radiata L. in response to chlorpyrifos. Int. J. Environ. Sci. Technol. 9, 605-612. doi:http:// dx.doi.org/10.1007/s13762-012-0095-x.

Pietsch, C., Krause, E., Burnison, B.K., Steinberg, C.E.W., Pflugmacher, S., 2006. Effects and metabolism of the phenylurea herbicide isoproturon in the submerged macrophyte Ceratophyllum demersum L. J. Appl. Bot. Food Qual. 30, 25-30.

Pozo, K., Llanos, Y., Estellano, V.H., Cortés, S., Jorquera, H., Gerli, L., Pozo, K., Encina, F. Palma, R., Focardi, S., 2016. Occurrence of chlorpyrifos in the atmosphere of the Araucanía Region in Chile using polyurethane foam-based passive air samplers. Atmos. Pollut. Res. 7, 706-710 doi:http://dx doi.org/10.1016/j.apr.2016.03.003.

Prasertsup, P., Ariyakanon, N., 2011. Removal of chlorpyrifos by water lettuce (Pistia stratiotes L.) and duckweed (Lemna minor L.). Int. J. Phytoremed. 13, 383-395. doi:http://dx.doi.org/10.1080/15226514.2010.495145.

Regoli, F., Giuliani, M.E., Benedetti, M., Arukwe, A., 2011. Molecular and biochemical biomarkers in environmental monitoring: a comparison of biotransformation and antioxidant defense systems in multiple tissues. Aquat. Toxicol. 105S, 5666. doi:http://dx.doi.org/10.1016/j.aquatox.2011.06.014

Ridgeway, G., 2013. GBM: Generalized Boosted Regression Models. R Package Version 2.1. http://CRAN.R-project.org/package =gbm.

Roberts, T.R., Hutson, D.H., 1999. Metabolic pathways of agrochemicals. Part 2 : Insecticides and Fungicides, Journal of Chemical Information and Modeling. The Royal Society of Chemistry, Cambridge UK doi:http://dx.doi.org/10.1017/ CB09781107415324.004.

Schweikert, K., Burritt, D.J., 2012. The organophosphate insecticide Coumaphos induces oxidative stress and increases antioxidant and detoxification defences in the green macroalgae Ulva pertusa. Aquat. Toxicol. 122-123, 86-92. doi http://dx.doi.org/10.1016/j.aquatox.2012.05.003.

Singh, D.P., Khattar, J.I.S., Nadda, J., Singh, Y., Garg, a., Kaur, N., Gulati, a., 2011. Chlorpyrifos degradation by the cyanobacterium Synechocystis sp. strain PUPCCC 64. Environ. Sci. Pollut. Res. 18, 1351-1359. doi:http://dx.doi.org/ 10.1007/s11356-011-0472-X.

Song, N.H., Yin, X., Le Chen, G.F., Yang, H., 2007. Biological responses of wheat (Triticum aestivum) plants to the herbicide chlorotoluron in soils. Chemosphere 68, 1779-1787. doi:http://dx.doi.org/10.1016/j.chemosphere.2007.03.023.

Swanson, S., Collen, R., Freemark, K., MacQuarrie, P., 1991. Testing for pesticide toxicity to aquatic plants: recommendations for test species. Plants Toxic. Assessm. 2, 77-97.

Tanaka, K., Sano, T. Ishizuka, K., Kitta, K., Kawamura, Y., 1994. Comparison of properties of leaf and root glutathione reductases from spinach. Physiol. Plant. 91, 353-358. doi:http://dx.doi.org/10.1111/j.1399-3054.1994.tb02960.x.

Valavanidis, A., Vlahogianni, T., Dassenakis, M., Scoullos, M., 2006. Molecular biomarkers of oxidative stress in aquatic organisms in relation to toxic environmental pollutants. Ecotoxicol. Environ. Saf. 64, 178-189. doi:http://dx. doi.org/10.1016/j.ecoenv.2005.03.013.

Van Wijngaarden, R.P.A., Brock, T.C.M., Van Den Brink, P.J., 2005. Threshold levels for effects of insecticides in freshwater ecosystems: a review. Ecotoxicology 14, 355-380. doi:http://dx.doi.org/10.1007/s10646-004-6371-x.

Ven Eerd, L.L., Hoagland, R.E., Zablotowicz, R.M., Hall, J.C., 2003. Pesticide metabolism in plants and microorganisms: an overview. Weed Sci. 51, 472-495. doi:http://dx.doi.org/10.1021/bk-2001-0777.ch001.

Wang, X., Li, J., Xing, H., Xu, S., 2011. Review of toxicology of atrazine and chlorpyrifos on fish. J. Northeast Agric. Univ. (English Ed.) 18, 88-92. doi:http:// dx.doi.org/10.1016/S1006-8104(12)60031-2.

Wang, X., Xing, H., Jiang, Y., Wu, H., Sun, G., Xu, Q., Xu, S., 2013. Accumulation, histopathological effects and response of biochemical markers in the spleens and head kidneys of common carp exposed to atrazine and chlorpyrifos. Food Chem. Toxicol. 62, 148-158. doi:http://dx.doi.org/10.1016/j.fct.2013.08.044.

Wintermans, J.F., de Mots, A., 1965. Spectrophotometric characteristics of chlorophylls $\mathrm{a}$ and $\mathrm{b}$ and their pheophytins in ethanol. Biochim. Biophys. Acta 109, 448-453. doi:http://dx.doi.org/10.1016/0926-6585(65)90170-6.

Yadav, N.R., 2015. Toxic effect of chlorpyrifos and dimethoate on protein and chlorophyll-a content of spirulina platensis. Int. J. Eng. Sci. Adv. Technol. 1, 2426.

van der Oost, R., Beyer, J., Vermeulen, N.P.E., 2003. Fish bioaccumulation and biomarkers in environmental risk assessment: a review. Environ. Toxicol. Pharmacol. 13, 57-149. doi:http://dx.doi.org/10.1016/S1382-6689(02)00126-6. 